\title{
Update of recent rates of carbon accumulation in bogs of Northern Patagonia-Chile
}

\author{
Carolina A. León ${ }^{1 *}$, Alfonso Benitez-Mora ${ }^{1}$, Gisela Oliván ${ }^{2}$ \\ ${ }^{I}$ Centro de Investigación en Recursos Naturales y Sustentabilidad, Universidad Bernardo O'Higgins, Av. Viel \\ 1497, Santiago, Chile. ${ }^{2}$ Departamento de Biología Vegetal I, Facultad de Ciencias Biológicas, Universidad \\ Complutense de Madrid, E-28040, Madrid, España.*Corresponding author: carolina.leon@ubo.cl
}

\begin{abstract}
Peatlands are one of the most important carbon cycle regulatory ecosystems, and are influenced by global climate change. However, studies of this kind of wetland are scarce in southern South America. In this study we performed a detailed analysis of recent accumulation rates of carbon (RERCA) in two types of Sphagnum peatland in Isla Grande de Chiloé (Chile) $\left(42^{\circ}-43^{\circ} \mathrm{S}\right.$ and $\left.75^{\circ}-73^{\circ} \mathrm{W}\right)$. Monoliths of peat in continuous depths were analyzed and assigned ages using $210 \mathrm{~Pb}$ dating. The results showed a difference between the two types of peatland; the average rate for the anthropogenic peatland $\left(107.34 \pm 113.9 \mathrm{~g} \mathrm{C} \mathrm{m}^{-2} \mathrm{yr}^{-1}\right)$ was superior to that of the natural peatland $\left(78.33 \pm 77.1 \mathrm{~g} \mathrm{C} \mathrm{m}^{-2} \mathrm{yr}^{-1}\right)$. The surface profiles $(30 \mathrm{~cm})$ clearly revealed the recent rate of carbon accumulation for the past 100 years in Sphagnum peatlands of Northern Patagonia. The rate for the natural peatland is within the range found for ombrotrophic peatlands in the Northern Hemisphere. However, the rate estimated for the anthropogenic peatland was significantly greater than those reported in other parts of the world. Our results provide evidence of the importance of these unique ecosystems in the carbon accumulation process.
\end{abstract}

Keywords: Carbon, RERCA, peatlands, $\mathrm{Pb}-210$, southern South America.

\section{Introduction}

Peatlands are one of the most important carbon cycle regulatory ecosystems, and are influenced by global climate change (Rydin and Jeglum, 2006). These wetlands are the most space-effective $\mathrm{C}$ stocks of all terrestrial ecosystems, storing up to ten times more $\mathrm{C}$ per ha than any other ecosystem (Joosten and Couwenberg, 2008). It represents $3-6 \%$ of the earth's land surface 
and about one third of the global soil $\mathrm{C}$ pool, and the same amount of $\mathrm{C}$ as all terrestrial biomass on earth (Charman, 2002). Although peatlands sequester carbon dioxide $\left(\mathrm{CO}_{2}\right)$ as peat, they can also become potential emitters of the two most important greenhouse gasses $\left(\mathrm{CO}_{2}\right.$ and $\left.\mathrm{CH}_{4}\right)$ due to destabilization of the development or dynamics of these ecosystems. These potential impacts on the greenhouse effect and climate change would be critical, considering that peatlands would become greenhouse gas emitters rather than collectors, which would aggravate the already serious situation (Augustin et al., 2011). The process begins when dry peat soils are in contact with air, which leads to the oxidation and decomposition of these soils, releasing $\mathrm{CO}_{2}$ (Joosten and Couwenberg, 2008). Some estimations indicate that peatland degradation contributes up to $0.8 \mathrm{Gt} \mathrm{C}$ per year (Trumper et al., 2009).

Carbon sequestration in peatlands is a key element to understand the global $\mathrm{C}$ cycle. It is estimated in different timescales to ascertain the role of these ecosystems in global warming due to rising atmospheric $\mathrm{CO}_{2}$ (Bao et al., 2010). One of the methods used to estimate $\mathrm{C}$ accumulation in peat is the assessment of recent rate of carbon accumulation (RERCA). This refers to the fresh peat that is annually added to the peatland system (Joosten and Couwenberg, 2008). Numerous studies on recent peatland carbon dynamics have been conducted in Europe, North America and Asia (Ali et al., 2008; Bao et al., 2010; Kareksela et al., 2015; Tolonen and Turunen, 1996; Turunen et al., 2004). Nevertheless, similar studies are scarce in South America; Loisel and Yu (2013) estimated that Patagonian peatlands have a mean soil carbon density of 168 $\mathrm{kg} \mathrm{C} \mathrm{m}{ }^{-2}$, while Cabezas et al, (2015) estimated a carbon stock of $11.99 \mathrm{~kg} \mathrm{C} \mathrm{m}^{-2}$ in Chiloé. León and Oliván (2014) presented a comparative analysis of RERCA and the recent rate of nitrogen accumulation (RERNA) in anthropogenic and natural peatlands of the Isla Grande de Chiloé (Chile) in some sections of the monoliths at non-continuous depths, providing a first approximation of carbon accumulation rates. In this study, the CIC (constant initial concentration) model was used to obtain the dating records. Bao et al, (2011) reported that the constant rate of supply (CRS) model is the best model to reconstruct recent peat chronologies. However, The CRS model may give nonsensical results if there are gaps in the sediment record (Appleby, 1998), thus this model was not used in the previous study.

The present study corrects this methodological problem and provides better chronologies. Some peatlands in the Southern Hemisphere were formed by peat accumulation in open fresh water bodies after glacial retreat (Heusser, 1984) through a terrestrialization process. In Chilean Patagonia, soil paludification caused by human activities (e.g. forest removal) has contributed significantly to the presence of peatlands in the last centuries (Díaz et al., 2008). Forest cover removal via fire or intense logging promotes paludification, since tree removal reduces evapotranspiration and increases the wetness of the soil organic layer (Díaz et al., 2008). Waterlogged and acidic soils hamper plant growth and establishment, as well as forest regeneration (Díaz et al., 2008). Hence high precipitation combined with low evapotranspiration can favor the establishment of peatlands over forests (Díaz et al., 2008). These "anthropogenic" peatlands differ substantially from natural peatlands in flora and levels of carbon storage. Indeed, studies in south- 
ern Chile suggest that differences in floristic composition among peatlands could actually be used to distinguish between natural and anthropogenic peatlands (Díaz et al., 2008; León et al., 2014). Natural peatlands are usually raised Sphagnum bogs with low shrub density, while anthropogenic peatlands present a dominant shrub cover of Empetrum rubrum, Tepualia stipularis and Baccharis patagonica. Species such as Cryptochila grandiflora, Drosera uniflora and Pinguicula antarctica are common in natural peatlands, but have not been found in anthropogenic peatlands, while anthropogenic peatlands include Kindbergia praelonga, Calliergonella cuspidate, Sanionia uncinata and Plagiochila lechleri, species never found in natural peatlands (León et al., 2014). Anthropogenic peatlands also have a greater diversity of lichens than natural peatlands (León et al., 2014). León and Oliván (2014) showed that there is a significant difference in the storage of $\mathrm{C}$ between the two types of peatlands. Anthropogenic peatlands have higher accumulation rates of carbon $(48.2 \pm 18.2$ $\mathrm{g} \mathrm{C} \mathrm{m}^{-2}$ year $^{-1}$ mean) than natural peatlands (12.4 $\pm 6 \mathrm{~g} \mathrm{C} \mathrm{m}^{-2}$ year $^{-1}$ mean). However, this study had methodological limitations, as mentioned above. Therefore, it is necessary to improve the model to reconstruct recent peat chronologies, using the CRS model to estimate carbon accumulation accurately, and to compare the accumulation in a global context. This study performed a detailed RERCA analysis in two bogs in order to improve the understanding of the role that peatlands of Chiloé play in the global carbon cycle and climate change.

\section{Materials and Methods}

\subsection{Study area}

The studies were conducted on Isla Grande de Chiloé $\left(42^{\circ}-43^{\circ} \mathrm{S}\right.$ and $\left.73^{\circ}-74^{\circ} \mathrm{W}\right)$, a continental island situated in Northern Chilean Patagonia, with a wet temperate climate and a strong oceanic influence an annual mean temperature of $9.6^{\circ} \mathrm{C}$ and rainfall range from 1,900-2,300 $\mathrm{mm}$ which may exceed $5,000 \mathrm{~mm}$ in some areas (di Castri and Hajek, 1976; Pérez et al., 2003; Carmona et al., 2010). Two locations were analyzed: Los Caulles (CAA), a natural peatland and Teguel (TGD), an anthropogenic peatland (Figure 1). These two kinds of Sphagnum peatlands were identified following the classification criteria of Díaz et al, (2008). Natural peatlands, originated after the last glaciation and anthropogenic peatlands are originated from poor soil drainage areas colonized by Sphagnum moss after the burning or logging of forests (Díaz et al. 2008; Zegers et al., 2006). CAA is a natural peatland, dominated by lax cushions of Sphagnum magellanicum, these cushions are associated with other bryophytes such as Cryptochila grandiflo$r a$ and an indicator species of natural peatlands Drosera uniflora. CAA has a low cover of dwarf shrubs and isolated trees such as Pilgerodendron uviferum and Nothofagus dombeyi. TGD is an anthropogenic peatland with numerous lax cushions of Sphagnum magellanicum; and with a high cover ( $60 \%)$ of shrubs such as Empetrum rubrum and Tepualia stipularis, and no carnivorous plants have been recorded. 


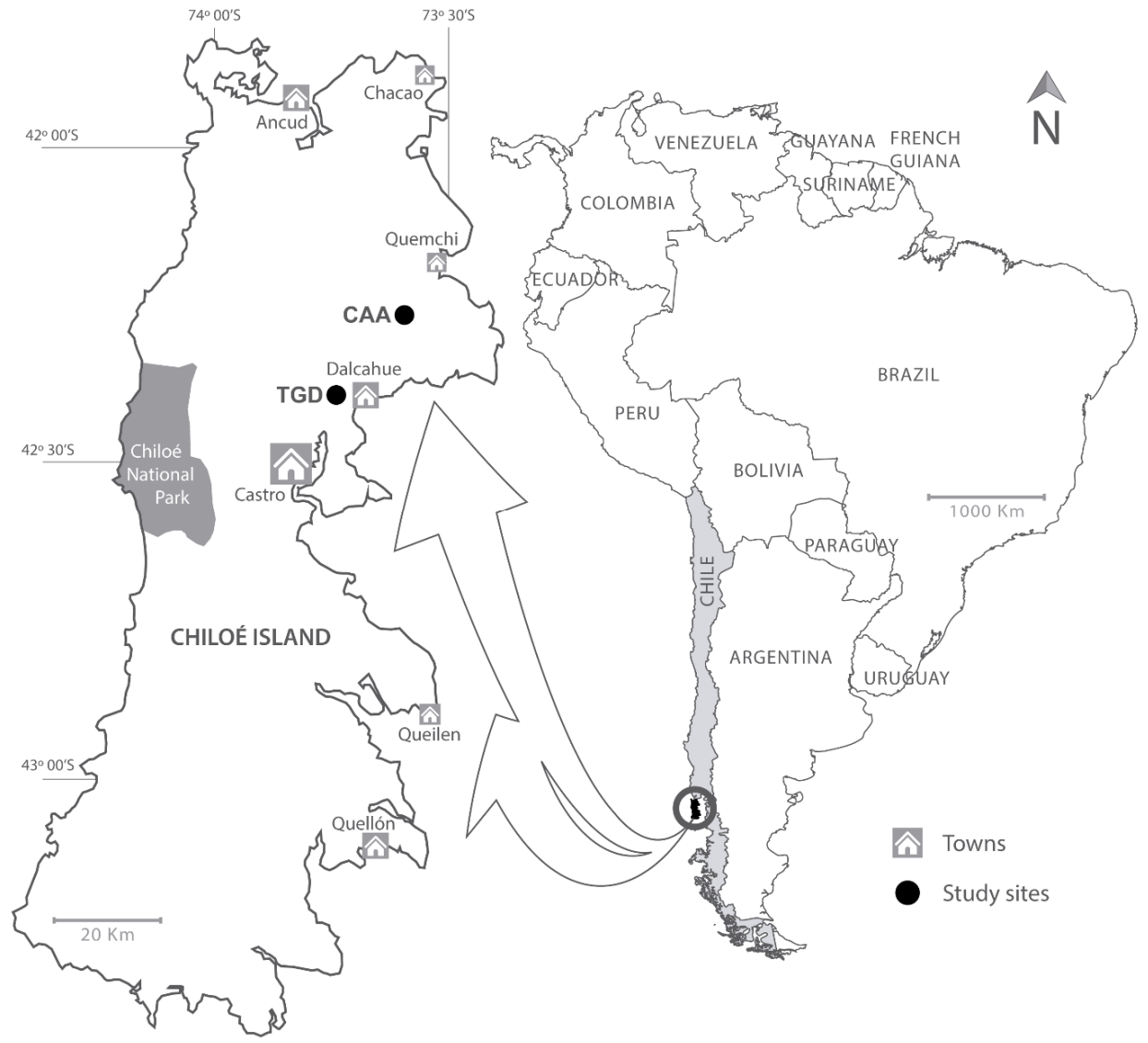

Figure 1. Study sites on Isla Grande de Chiloé. CAA, natural peatland and TGD, anthropogenic peatland.

\subsection{Sampling and physicochemical analysis}

The peatlands sampled were composed of Sphagnum peat, mainly Sphagnum magellanicum. In each sampling site, a short peat monolith $(30 \times 30 \times 45-50 \mathrm{~cm})$ was extracted using a sharpened metal sheet, following the methods of De Vleeschouwer et al. (2010). The monoliths were carefully extracted, wrapped in foil pa- per and transported in flat rigid cases to be subsampled later. Monoliths were cut and separated into intervals of $2 \mathrm{~cm}$. Two sub-samples were taken of each segment: one to calculate the density of peat (bulk density) with a small portion of $2 \mathrm{~cm}^{3}$, and the other with the rest of the material to estimate $\mathrm{C}$ content. Each segment was deposited in a polyethylene bag and taken to the laboratory under refrigeration. 
A known volume and weight of a peat section was dried at $105{ }^{\circ} \mathrm{C}$ for 12 hours to determine the water content and dry bulk density from weight loss by drying. Water content was calculated by taking a sample of peat, drying at 105 ${ }^{\circ} \mathrm{C}$ to obtain water content in $\mathrm{g}$, expressing water content per dry mass of sample (Rydin and Jeglum, 2006). Dry bulk density was calculated by the ratio of dry weight to the initial known volume (Bao et al., 2010; Sadzawka et al., 2006). Ash content was obtained in a muffle furnace by combustion at $550{ }^{\circ} \mathrm{C}$ for six hours and this parameter was expressed as a percentage of the total sample analyzed (Bao et al., 2010; Sadzawka et al., 2006). Organic carbon was calculated by multiplying the organic matter by 0.50 , following Tolonen and Turunen (1996) and Bao et al. (2010). This coefficient is widely used to relate biomass and productivity to $\mathrm{C}$ cycling, the rough convention is $0.5 \mathrm{~g}$ carbon in $1 \mathrm{~g}$ dry biomass (Rydin and Jeglum, 2006).

\subsection{Radiometric measurements}

Radioisotope dating of $\mathrm{Pb}-210$ was performed at the Servicio de Radioisótopos of the Universidad de Sevilla (Spain) using gamma spectrometry with a well-type High-purity Germanium Detector (HPGe). Chronologies were obtained by applying the CRS (Rate Constant Supply) model (Appleby and Oldfield, 1978). All sections of the extracted profiles were studied. To estimate RERCA (Recent Rate of Carbon Accumulation), data for dry density, $\mathrm{C}$ content and age were used in the model described by Bao et al. (2010).

\section{Results}

The water content of the different components of RERCA ranged from $842-3057 \%$ with a mean of $1777 \%$. The TGD profile had lower water content than the CAA profile along the whole monolith. At both sites, continuous variation was seen from the surface layers to the deeper layers (Figure 2A).

The overall variation range of dry density was $0.0190-0.081 \mathrm{~g} / \mathrm{cm}^{3}$, with an overall mean of $0.036 \mathrm{~g} / \mathrm{cm}^{3}$. The CAA sampling site showed slight variations along the monolith and a lower density compared to the TGD site. TGD also showed little variation except at 8 and $32 \mathrm{~cm}$, where significant increases were observed (Figure 2B).

Ash content ranged from $0.1-2.4 \%$, with a mean of $1.3 \%$. Moderate variation was observed along the monolith at the CAA site. The TGD site showed a decrease in ash content from the surface to 12 and $14 \mathrm{~cm}$ and a gradual increase to $32 \mathrm{~cm}$, subsequently presenting an abrupt decrease. Carbon content of the sampled monoliths varied between 48.8 and $49.95 \%$ with a mean of $49.33 \%$. CAA showed moderate and irregular variation from the surface to the deeper layers. In contrast, TGD showed more pronounced variation (Figure 2C). $\mathrm{Pb}-210$ and $\mathrm{Ra}-226$ isotope activity concentrations $\left(\mathrm{Bq} \mathrm{kg}{ }^{-1}\right)$ were well defined for both profiles up to a depth of $30 \mathrm{~cm}$ (Figue 2D). 

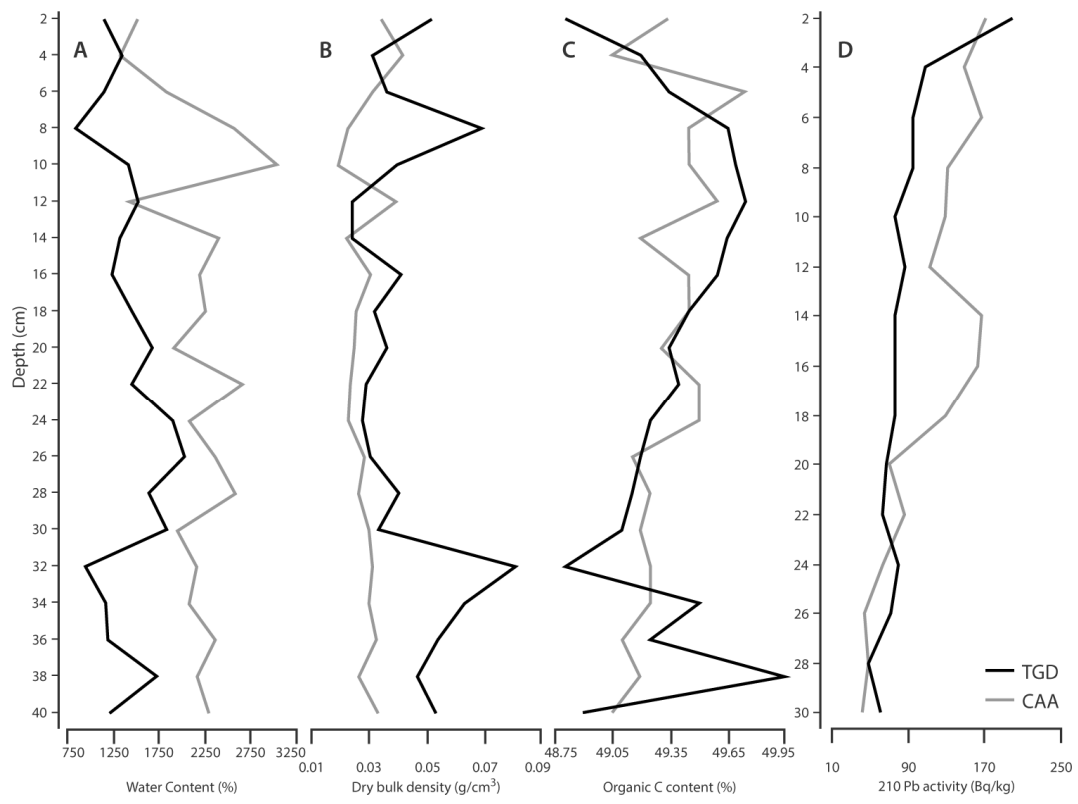

Figure 2. Variation of (A) water content (\%), (B) dry bulk density $\left(\mathrm{g} \mathrm{cm}^{-3}\right),(\mathrm{C}) \mathrm{C}$ content (\%), and (D) $210 \mathrm{~Pb}$ activity $\left(\mathrm{Bq} \mathrm{kg}^{-1}\right)$. Sites: TGD, Teguel (anthropogenic peatland) and CAA, Caulles (natural peatland).

Estimated values for RERCA are presented in Figure 3. The TGD site showed variation between 49.84 and $507.52 \mathrm{~g} \mathrm{C} \mathrm{m}^{-2} \mathrm{yr}^{-1}$. At the CAA site, RERCA ranged from 33.49 to $335.58 \mathrm{~g} \mathrm{C} \mathrm{m}^{-2} \mathrm{yr}^{-1}$. Both profiles showed reduced recent rates of carbon accumulation in deeper layers. The average rate of the profile for TGD $(107.34 \pm 113.9)$ was superior to that of CAA $(78.33 \pm 77.1)$. Taking these results as a basis, by way of illustration it could be extrapolated that in the last 100 years carbon accumulation rates in peatlands of Chiloé have ranged between 33.49 and $507.52 \mathrm{~g} \mathrm{C} \mathrm{m}^{-2} \mathrm{yr}^{-1}$ with a mean of $92.84 \mathrm{~g} \mathrm{C} \mathrm{m}^{-2} \mathrm{yr}^{-1}$. 


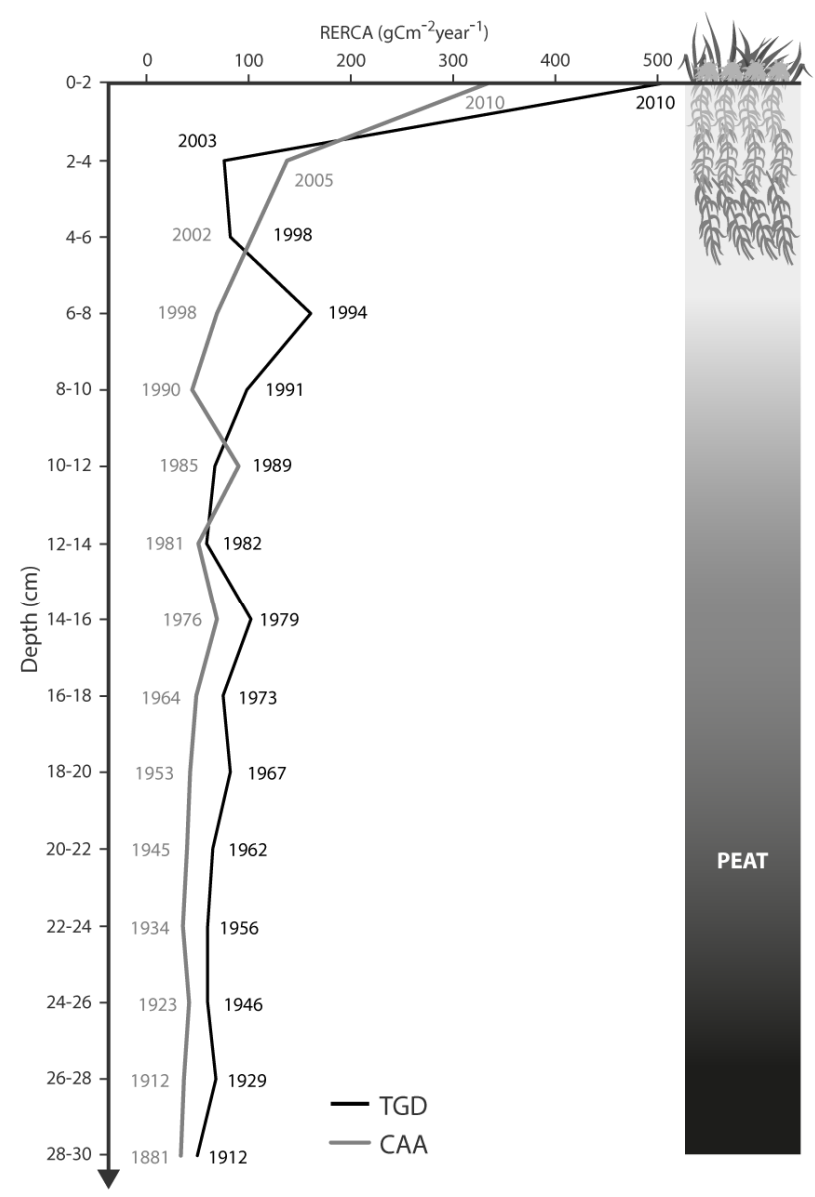

Figure 3. Recent rates of C (RERCA) accumulation in the studied localities. Sites: TGD, Teguel (anthropogenic peatland) and CAA, Caulles (natural peatland). Calendar years (AD) are shown together for each RERCA.

\section{Discussion}

The upper soil layers $(30 \mathrm{~cm})$ clearly revealed the recent rate of carbon accumulation for the past 100 years in Sphagnum peatlands of Northern Patagonia. Our results showed a difference between the two types of peatland studied. A clear increase in $\mathrm{C}$ towards the shallower segments was observed in the two profiles. However, the TGA (anthropogenic peatland) showed greater rates than CAA (natural peatland) (Figure 3). These results are consistent with other studies in boreal Sphagnum peatlands which suggest that rates of carbon accumulation are considerably higher in deposits of young peat and the mean carbon accumulation decreases over time by the slow decomposition that occurs in deeper and anoxic layers of peat (Tolonen and Turunen, 1996; Turunen et al., 2004). 
These differences between anthropogenic and natural peatland were also reported by León and Oliván (2014). Nevertheless, our analysis shows differences in the magnitude and time scale. This can be explained by the methodological limitations mentioned above. Due to the more accurate chronology, the RERCA estimations made in the present study can be used to compare carbon accumulation values with other geographical areas. There are recent studies available on $\mathrm{C}$ accumulation performed in different parts of the world, using different dating methods (Figure 4). The average $\mathrm{C}$ accumulation rate in eastern Canadian ombrotrophic bogs over the last 150 years was $73 \mathrm{~g} \mathrm{C}$ $\mathrm{m}^{-2} \mathrm{yr}^{-1}$ (Turunen et al., 2004). Tolonen and Turunen (1996) reported variation from 39.8 to $80.7 \mathrm{~g} \mathrm{C} \mathrm{m}^{-2}$ $\mathrm{yr}^{-1}$ in mire of western Finland during the last 212-147 years. Our result was similar $\left(78.3 \mathrm{~g} \mathrm{C} \mathrm{m}^{-2} \mathrm{yr}^{-1}\right)$ in the natural peatland. However, the anthropogenic peatland had a rate (107.3 $\mathrm{g} \mathrm{C} \mathrm{m}^{-2} \mathrm{yr}^{-1}$ mean) much higher than those reported in other latitudes, showing values similar to the Everglades (USA) (Craft and Richardson, 1993). These results could be explained in part by the youth and dynamics of this type of ecosystem. Anthropogenic peatlands have been considered as novel ecosystems; they have a new species composition that has deeply changed the landscape and ecosystem services (León et al., 2016). Our results provide evidence of the importance of these unique ecosystems, and show that the knowledge regarding the biodiversity, biogeochemistry, and ecological processes is very limited at the moment. For example, we do not know which microorganisms act in the recycling of nutrients which could be favoring carbon accumulation.

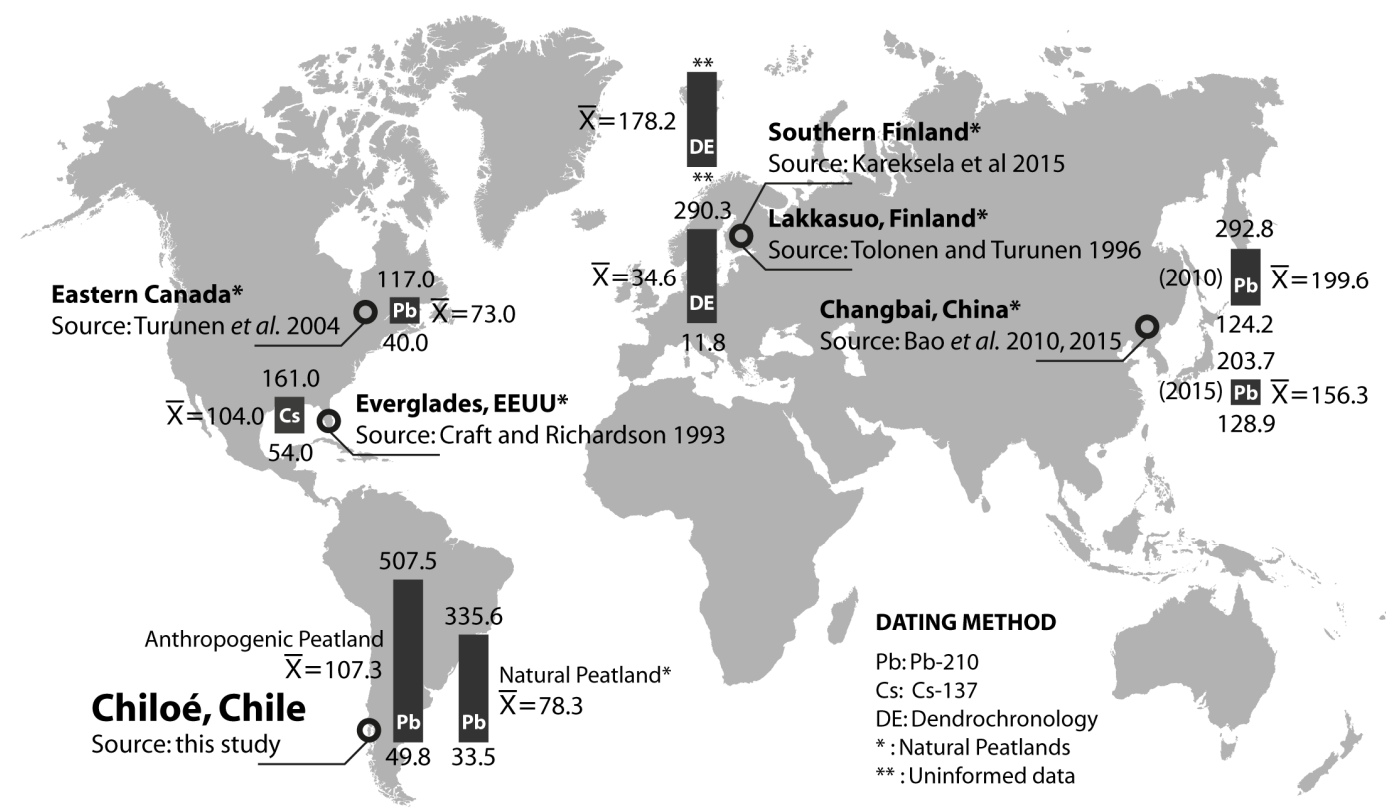

Figure 4. RERCA in peatlands around the world. Maximum, minimum and mean in $\mathrm{g} \mathrm{C} \mathrm{m}^{-2} \mathrm{yr}^{-1}$. Age dating: $\mathrm{Pb}$, ${ }^{210} \mathrm{~Pb}$; Cs, ${ }^{137} \mathrm{Cs}$; DE, dendrochronology. Uninformed data: data not reported in the study. 
Using the results presented here, we could extrapolate a mean of $9.3 \mathrm{Kg} \mathrm{m}^{-2}$ carbon storage in the last 100 years in Chiloé. If the total area covered by peatland calculated in the first inventories of peat in Chiloé carried out by SERNAGEOMIN \& GORE-Los Lagos (2008) is considered $\left(106.27 \mathrm{~km}^{2}\right)$ and around 980,000 tons of carbon may have been accumulated during the last century in the Isla Grande of Chiloé. Moreover, if we use the minimum stock calculated for the peatland in Chiloé (SERNAGEOMIN and GORE-LosLagos, 2008), which exceeds 2.7 million tons of peat and an average organic $\mathrm{C}$ content of $4933 \%$, the total potential stock of carbon would be over 1,242,000 tons in Chiloé alone. All of these values highlight the important role of these ecosystems in carbon flux. The amount of stored $\mathrm{C}$, which could be released as $\mathrm{CO}_{2}$ if the peatlands were drained, is enormously significant. This research provides data on the accumulation of $\mathrm{C}$ in one of the Patagonian areas where these ecosystems are being highly threatened. Peatlands have become important in Chile due to the interest generated in the extraction and trade of Sphagnum moss (Agüero, 2013). The commercial interest in horticultural Sphagnum has grown progressively over the last 15 years. In 2017, more than 3,500 tons of dried moss were exported, with $75 \%$ coming from the Los Lagos Region (ODEPA, 2018). Moreover, in Chiloé, peatlands play a key role in the fresh water supply. This island has no freshwater input from snowmelt as on mainland Chile. The freshwater input is mainly from precipitation and it is accumulated in peatlands that function as huge sponges, being the only fresh water reserves in the island (Zegers et al., 2006). Thus, the conservation of the biomass and ecological functions also affects the wellness of the local community, since it promotes the accumulation of fresh water.

Finally, these results have impact on local and global scales. In a local context, this study illustrates the role of peatlands as carbon reservoirs and predicts the consequences of their degradation. Degraded peatlands can also become potential emitters of $\mathrm{CO}_{2}$ (Augustin et al., 2011). We hope that this information will be used by the decision-makers to promote the conservation of these ecosystems. Globally, better estimates of carbon stocks and dynamics are needed for improved understanding of the carbon balance and potential for climate change mitigation (Scharlemann et al., 2014), ecosystem services provided (Oso and Rajashekhar, 2017) and the relationship with other systems (Tian et al., 2016). Data on C accumulation in South American peatlands are scarce, therefore our results are useful for a complete picture of the global $\mathrm{C}$ cycle.

\section{Conclusion}

This study provides updated baseline data on RERCA for the past 100 years in Sphagnum peatlands of Northern Patagonia. These values are within the range given for ombrotrophic peatlands in the Northern Hemisphere, especially in natural peatlands. The anthropogenic peatland however, showed a rate significantly greater than those reported in other parts of the world. Our results provide evidence of the importance of these unique ecosystems in the carbon accumulation process. Nevertheless, reliable information on long-term carbon accumulation and exchange is necessary to define clear policies and sustainable management towards the safeguarding of natural heritage and for climate change mitigation policies.

\section{Acknowledgements}

This research was supported by grants from FONDECYT 11150275, AECID A/025081/2009, Cooperación al Desarrollo UCM 4138114, and AECID $\mathrm{A} / 030011 / 2011$. We are very grateful to anonymous 
reviewers for their constructive suggestions. This is a contribution to the Research Program of LTSERChile network at Senda Darwin Biological Station, Chiloé, Chile.

\section{References}

Agüero, T. 2013. Musgo Sphagnum: manejo sostenible del recurso. Oficina de Estudios y Políticas Agrarias (ODEPA), Santiago de Chile.

Ali, A.A., Ghaleb, B., Garneau, M., Asnong, H., Loisel, J. 2008. Recent peat accumulation rates in minerotrophic peatlands of the Bay James region, Eastern Canada, inferred by $210 \mathrm{~Pb}$ and $137 \mathrm{Cs}$ radiometric techniques. Appl. Radiat. Isotopes. 66, 1350-1358.

Appleby, P.G. 1998. Dating recent sediments by 210 $\mathrm{Pb}$ : problems and solutions, in: Ilus, E. (Ed.), Dating of sediments and determination of sedimentation rate. Proceedings of a seminar held in Helsinki 2 - 3 April 1997, Helsinki, Finland, pp: 7-24.

Appleby, P.G., Oldfield, F. 1978. The calculation of lead-210 dates assuming a constant rate of supply of unsupported $210 \mathrm{~Pb}$ to the sediment. CATENA. 5, 1-8.

Augustin, J., Couwenberg, J., Minke, M. 2011. Peatlands and greenhouse gases, in: Tanneberger, F., Wichtmann, W. (Eds.), Carbon credits from peatland rewetting: climate, biodiversity, land use. Schweizerbart science, Stuttgart, Germany, pp: 13-19.

Bao, K., Yu, X., Jia, L., Wang, G. 2010. Recent carbon accumulation in Changbai mountain peatlands, Northeast China. Mt. Res. Dev. 30, 33-41.

Bao, K., Zhao, H., Xing, W., Lu, X., McLaughlin, N.B., Wang, G. 2011. Carbon Accumulation in Temperate Wetlands of Sanjiang Plain, Northeast China. 75, 2386-2397.
Cabezas, J., Galleguillos, M., Valdés, A., Fuentes, J.P., Pérez, C., Perez-Quezada, J.F. 2015. Evaluation of impacts of management in an anthropogenic peatland using field and remote sensing data. Ecosphere. 6, 1-24.

Carmona, M.R., Aravena, J.C., Bustamante-Sanchez, M.A., Celis-Diez, J.L., Charrier, A., Díaz, I.A., Díaz-Forestier, J., Díaz, M.F., Gaxiola, A., Gutiérrez, A.G., Hernandez-Pellicer, C., Ippi, S., Jaña-Prado, R., Jara-Arancio, P., Jimenez, J., Manuschevich, D., Necochea, P., Nuñez-Avila, M., Papic, C., Pérez, C., Pérez, F., Reid, S., Rojas, L., Salgado, B., Smith-Ramírez, C., Troncoso, A., Vásquez, R.A., Willson, M.F., Rozzi, R., Armesto, J.J. 2010. Estación Biológica Senda Darwin: investigación ecológica de largo plazo en la interfase ciencia-sociedad. Rev. Chil. Hist. Nat. 83, 113-142.

Craft, C.B., Richardson, C.J. 1993. Peat Accretion and N, P, and Organic C Accumulation in Nutrient-Enriched and Unenriched Everglades Peatlands. Ecol. Appl. 3, 446-458.

Charman, D., 2002. Peatlands and environmental change. J. Wiley \& Sons, London \& New York, $301 \mathrm{p}$.

De Vleeschouwer, F., Chambers, F.M., Swindles, G.T. 2010. Coring and sub-sampling of peatlands for palaeoenvironmental research. Mires and Peat. 7, $1-10$.

Di Castri, F., Hajek, E.R. 1976. Bioclimatología de Chile. Editorial Universidad Católica de Chile, Santiago, Chile, 128 p.

Díaz, M.F., Larraín, J., Zegers, G., Tapia, C. 2008. Caracterización florística e hidrológica de turberas de la Isla Grande de Chiloé, Chile. Rev. Chil. Hist. Nat. 81, 445-468. 
Gaxiola, A., McNeill, S.M., Coomes, D.A. 2010. What drives retrogressive succession? Plant strategies to tolerate infertile and poorly drained soils. Func. Ecol. 24, 714-722.

Heusser, C.J. 1984. Late glacial holocene climate of the Lake District of Chile. Quatern. Res. 22, 7790.

Joosten, H., Couwenberg, J. 2008. Peatlands and carbon, in: Parish, F., Sirin, A., Charman, D., Joosten, H., Minayeva, T., Silvius, M., Stringer, L. (Eds.), Assessment on peatlands, biodiversity and climate change: main report Global Environment Centre, Kuala Lumpur and Wetlands International, Wageningen, pp: 99-117.

Kareksela, S., Haapalehto, T., Juutinen, R., Matilainen, R., Tahvanainen, T., Kotiaho, J.S. 2015. Fighting carbon loss of degraded peatlands by jumpstarting ecosystem functioning with ecological restoration. Sci. Total Environ. 537, 268-276.

León, C.A., Oliván, G. 2014. Recent rates of carbon and nitrogen accumulation in peatlands of Isla Grande de Chiloé-Chile. Rev. Chil. Hist. Nat. 87.

León, C.A., Oliván, G., Gaxiola, A. 2018. Environmental controls of cryptogam composition and diversity in anthropogenic and natural peatland ecosystems of Chilean Patagonia. Ecosystems. 21, 203-215.

León, C.A., Oliván, G., Larraín, J., Vargas, R. 2016. Patterns of bryophyte and lichen diversity in bogs and Tepualia stipularis forests of Northern Patagonia (Chile): evidence of a novel ecosystem in southern South America. Botanical Science. 94, 441-453.

León, C.A., Oliván, G., Larraín, J., Vargas, R., Fuertes, E. 2014. Bryophytes and lichens in peatlands and Tepualia stipularis forest of Isla Grande de Chiloé-Chile. An. Jard. Bot. Madr. 71, e003.
Loisel, J., Yu, Z. 2013. Holocene peatland carbon dynamics in Patagonia. Quatern. Sci. Rev. 69, 125141.

ODEPA. 2018. Exportaciones de musgos secos, distintos de los usados para ramos y adornos y de los medicinales. Código SACH 14049020. Estadísticas Comercio Exterior, Oficina de Estudios y Políticas Agrarias (ODEPA), Ministerio de Agricultura, Santiago, Chile.

Oso, V., Rajashekhar Rao, B.K. 2017. Land use conversion in humid tropics influences soil carbon stocks and forms. J. Soil Sci. Plant Nutr. 17, 543553.

Pérez, C.A., Armesto, J.J., Torrealba, C., Carmona, M.R. 2003. Litterfall dynamics and nitrogen use efficiency in two evergreen temperate rainforests of southern Chile. Austral Ecol. 28, 591-600.

Rydin, H., Jeglum, J.K. 2006. The Biology of Peatlands. Oxford University Press, London, 343 p.

Sadzawka, A., Carrasco, M.A., Grez, R., Mora, M.L., Flores, P., Neaman, A., 2006. Métodos de análisis de suelos recomendados para los suelos de Chile. Serie Actas INIA N ${ }^{\circ} 34$. Instituto de Investigaciones Agropecuarias, Santiago, Chile, 164 p.

Scharlemann, J., Tanner, E., Hiederer, R., Kapos, V. 2014. Global soil carbon: understanding and managing the largest terrestrial carbon pool. 5, 81-91.

SERNAGEOMIN, GORE-LosLagos. 2008. Catastro y levantamiento geológico de reservas explotables del recurso turba en Chiloé, Región de Los Lagos. Informe Final. Servicio Nacional de Geología y Minería - Gobierno Regional de Los Lagos, Santiago, 292 pp.

Tian, F.-P., Zhang, Z.-N., Chang, X.-F., Sun, L., Wei, X.-H., Wu, G.-L. 2016. Effects of biotic and abiotic factors on soil organic carbon in semi-arid grassland. J. Soil Sci. Plant Nutr. 16, 1087-1096. 
Tolonen, K., Turunen, J. 1996. Accumulation rates of carbon in mires in Finland and implications for climate change. Holocene. 6, 171-178.

Trumper, K., Bertzky, M., Dickson, B., van der Heijden, G., Jenkins, M., Manning, P. 2009. The Natural Fix? The role of ecosystems in climate mitigation. A UNEP rapid response assessment. United Nations Environment Programme. UNEPWCMC, Cambridge, UK.
Turunen, J., Roulet, N.T., Moore, T.R., Richard, P.J.H. 2004. Nitrogen deposition and increased carbon accumulation in ombrotrophic peatlands in eastern Canada, Global Biogeochemical Cycles, p. 12.

Zegers, G., Larraín, J., Díaz, M.F., Armesto, J.J. 2006. Impacto ecológico y social de la explotación de pomponales y turberas de Sphagnum en la Isla Grande de Chiloé. A\&D. 22, 28-34. 